\title{
Influence of preparative form on the target efficiency and toxicity of the solid insecticide based on pyrethroid and neonicatinoid
}

\author{
Andrey V. Tretiakov ab*(D), Sergey B. Yaroshuk ${ }^{b}$ (D), Vyacheslav F. Markov ac (D), \\ Lyudmila G. Budnik b iD
}

a: Institute of Chemical Engineering, Ural Federal University, 620002 Mira st., 19, Yekaterinburg,

Russia

b: "GET Biotechnology" Ltd, 620072 Constructors st., 5, Yekaterinburg, Russia

c: Department of scientific research, Ural Institute of State Fire Service of EMERCOM, 620022

Mira st., 22, Yekaterinburg, Russia

* Corresponding author: tretyakoff_93@mail.ru

This article belongs to the Regular Issue.

(C) 2021, The Authors. This article is published in open access form under the terms and conditions of the Creative Commons Attribution (CC BY) license (http://creativecommons.org/licenses/by/4.0/).

\section{Abstract}

The influence of solid preparative form was studied on the «GET Dry» insecticide based on alpha-cypermethrin and imidacloprid. The target efficiency as acute and residual impact was studied when agent was applied against the bedbugs (Cimex hemipterus), German cockroach (Blatella germanica), common house flies (Musca domestica) and larvae of the leather beetles (Attagenus smirnovi). The agent demonstrated strong acute effect (about 100\%) when applied against the cockroaches, bugs, and flies. Moreover, the agent demonstrates the residual impact on the cockroaches, flies, fleas for 45 days, and on the bugs for 30 days. The slight insecticidal activity was observed when the agent was applied against the larvae. We studied toxicity of the agent, $\mathrm{LD}_{50}$, when swallowed (moderately hazardous substances, class III) and when applied to the skin (low-hazard substance, class IV) as well as studied its inhalation hazard according to its volatility $C^{20}{ }^{\circ} \mathrm{C}$, irritant action when applied to the skin (slight) and eye irritation (moderate). Sensibilizing action was not observed.

\section{Keywords \\ solid form \\ insecticide \\ pyrethroid \\ neonicatinoid \\ target efficacy \\ toxicity}

Received: 24.11.2021

Revised: 11.01.2022

Accepted: 11.01.2022

Available online: 13.01 .2022

\section{Introduction}

In the world practice of disinsection, there is a shortage of effective and at the same time ready-to-use formulations. In the control of household crawling pests, the priority is given to the contact type of agents, which are blockers or inhibitors of acetylcholinesterase. If the formulation of the insecticide is ready for use, there is a possibility of low efficacy or high toxicity of the drug. Existing ready-made insecticides often have an intestinal (calcium, magnesium, barium arsenates, etc.) or fumigation (katfos, dichlorvos, etc.) principle of action; as a result, the disinsector is exposed to an additional risk of drug poisoning. In the case of domestic use, when the products are used by nonprofessionals, insecticides of these types of action can cause undesirable consequences due to the poisoning.

Taking this into account, specialists of "GET Biotechnology" Ltd (Yekaterinburg, Russia) have developed a ready- made insecticide with a contact type of action for use in everyday life [1]. The agent contains the active ingredients alpha-cypermethrin with a mass fraction of $3 \%$ and imidacloprid with a mass fraction of $0.4 \%$. These active ingredients have relatively low toxicity and resistance in most insects [2-4].

Alpha-cypermethrin (concord, renegade, fastak, fendon) - is an (S)- $\alpha$-cyano-3-phenoxybenzyl ester of (1R, 1S)-cis-3(2,2-dichlorovinyl)-2,2-dimethylcyclopropanecarboxylic acid (Fig. 1).

A similar solid insecticidal agent with contact action principle is known [5]. The use of an insecticide based on pyrethroids for the control of household pests was described in the patents [6-7]. Toxicological tests and monitoring of insecticide degradation were discussed in the article [8].

Alpha-cypermethrin is a contact-intestinal pyrethroid with repellent properties, effective in combating all stages of insect development. 


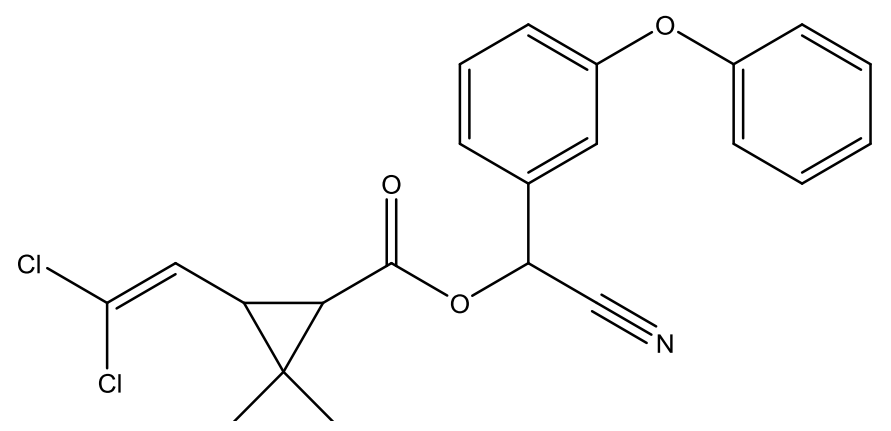

Fig. 1 Structural formula of alpha-cypermethrin

For a long time, it retains its insecticidal and acaricidal properties, and it is resistant to being washed out by rain. It is safe for bees, as it has a repellent effect on them - bees leave the site immediately after processing. Alphacypermethrin does not pose danger to mammals and birds [9].

Resistance to alpha-cypermethrin may be due to mutations in voltage-sensitive sodium channels (VSSCs) and enhanced detoxification by $\mathrm{P} 450$ monooxygenase. The authors of [10] included both components in insects to determine the effects of pyrethroids. Pyrethroid hydrolase in bacteria and $\mathrm{P} 450$ in insects are potential targets. Pyrethroid hydrolase was aimed at increasing the biodegradation of bacteria, and $\mathrm{P} 450$ was aimed at increasing insect sensitivity/resistance. Similarly, the chimeric $\mathrm{P} 450$ enzyme has been reported to be involved in pyrethroid resistance in Helicoverpa armigera (Hubner).

A study [11] reports on the effect of the presence of pyrethortroids in combination with other environmental pollutants (microplastics) on the vital activity of Chironomus riparius. Combined and single exposure to pyrethroids and microplastics affects vital traits and microbiomes, therefore, it is necessary to focus on effects at limited food levels because they can simulate realistic nutritional conditions in nature and indicate competition for food in the host microbiota.

The results of a study [12] show that ecologically significant concentrations of pyrethroids can disrupt the behavior of delta smelt larvae even at the lowest concentrations $(<1 \mathrm{ng} / \mathrm{L})$ and that salinity can alter the dynamics of pyrethroid toxicity in terms of behavioral effects, especially for bifenthrin, where salinity was positively correlated with antithigmotaxis at each concentration.

The aim of the study [13] was to investigate the enantiomerically specific acute toxicity for the earthworm Eisenia fetida and a potential mechanism through a multilevel response. Gut damage, changes in body weight, and DNA damage caused by oxidative stress may be the main mechanisms of tefluthrin toxicity to earthworms.

The authors of [14] report a strong correlation between surface area/volume and toxicokinetic (TK) parameters (rate constants of sorption and absorption and the resulting bioconcentration factors $(B C F)$ ), but none of the TK parameters correlated with sensitivity. The only parameter consistently correlating with sensitivity for all species was the death rate constant of the GUTS-RED-SD model (models with a reduced overall unified survival threshold, suggesting stochastic death), indicating that sensitivity to cypermethrin is more related to toxicodynamic (TD) parameters than the parameters of the TK.

Research [15] reports that due to its regulatory role at the initial stage of hydrolysis of the ester bond, esterase acts as a regulatory enzyme in all organisms in the case of pyrethroid metabolism. This family of enzymes exists in almost all life forms (bacteria, fungi, plants, animals), and pyrethroid degradation functions have been reported in all organisms. In insects, these enzymes play a role in pest resistance and have also been reported to have a detoxifying role in animals. Pesticides are not toxic to animals in low doses due to the presence of pyrethroid hydrolase isoenzymes. Bacteria and fungi produce pyrethroid hydrolase to degrade pyrethroid insecticides.

Based on the evidence that dopamine regulates behavior and studies showing that other pyrethroids affect the dopamine system, transcripts involved in dopaminergic signaling were measured. Researchers [16] found that the active dopamine transporter was inhibited with $0.2 \mathrm{mg} / \mathrm{L}$ of a similar pyrethroid insecticide, esfenvalerate.

The results of the study [17] showed that the administration of deltamethrin is associated with a significant decrease in reproductive hormones, especially $\mathrm{FSH}, \mathrm{LH}$, and a significant increase in the levels of interleukin 2 (IL2), interleukin 6 (IL6), histamine and cortisol. They also noted the importance of suppressing sperm motility and viability, reducing testicular weight, sperm count and fructose in sperm. These results clarify the deleterious effects of deltamethrin on the male reproductive system, causing significant changes in reproductive hormones, markers of inflammation, and testicular function.

The structure-activity relationships showed that substituents at the position of the chiral atom in the oxadiazine ring are very important for the biological activity of the oxadiazine insecticide. Zhang et al. [18] synthesized a series of derivatives of tricyclic oxadiazine 4a-methyl ester.

The authors of [19] created a NavMs-based cockroach sodium channel model in which pyrethrin II docked with the pyrethroid receptor 1 (PyR1) site and proposed a rationale for the observed structure-activity relationship of six pyrethrins. Our study shed light on the molecular mechanism of action of pyrethrum on sodium channels and revealed differences in the modes of action of the six biologically active components of pyrethrum.

$\mathrm{LD}_{50}$ of pyrethrum when introduced into the stomach, depending on the solvent and the species of animals, varies for mice $762.0 \mathrm{mg} / \mathrm{kg}$ (in corn oil), $35 \mathrm{mg} / \mathrm{kg}$ - in DMSO and $168 \mathrm{mg} / \mathrm{kg}$ - in 2\% starch gel; for rats in the range of $80-368 \mathrm{mg} / \mathrm{kg}$ in corn oil, $75 \mathrm{mg} / \mathrm{kg}$ - in ethyl 
alcohol, $208 \mathrm{mg} / \mathrm{kg}$ - in 2\% starch gel and according to State All-Union standard 12.1.007-76 it belongs to 2-3 hazard classes. $\mathrm{LD}_{50}$ when applied to the skin of rats is $500 \mathrm{mg} / \mathrm{kg}$, on the skin of rabbits $>2000 \mathrm{mg} / \mathrm{kg}$. $\mathrm{CL}_{50}$ for rats with 4 -hour inhalation exposure in the form of dust $>1300 \mathrm{mg} / \mathrm{m}^{3}$ (according to the active substance $>400 \mathrm{mg} / \mathrm{m}^{3}$ ). The clinical picture of acute poisoning is characterized by a neurotoxic type of action with impaired coordination of movements and the appearance of seizures, tremors, salivation, etc. The most affected organs are the nervous system, liver, and kidneys. In case of contact with eyes, it causes moderate irritation of the mucous membranes. Has a mild irritant effect on the skin of rabbits.

Cumulative activity of alpha-cypermethrin using the method of Yu.S. Kagan et al. is moderate $\left(C_{\text {cum }}=4.6\right)$. The skin-resorptive effect is poorly expressed. A weak sensitizing effect of the substance was established (the Magnusson-Kligman method on guinea pigs). Mutagenic activity, studied in various test systems in vivo and in vitro, has not been identified. Carcinogenic, embryotoxic and teratogenic effects have not been established. SRLI (safe reference level of impact) of alpha-cypermethrin in the air of the working area - $0.1 \mathrm{mg} / \mathrm{m}^{3}$; SRLI in atmospheric air $0.002 \mathrm{mg} / \mathrm{m}^{3}$.

Imidacloprid (admir, gauchko, copfidor, prime) is a 4,5-dihydro-N-nitro-1-[(6-[chloro-3-pyridyl)-methyl]imidazolidin-2-ylen-amine (Fig. 2).

Imidacloprid is a synthetic insecticide from the group of neonicatinoids, which, when ingested by an insect, suppresses the activity of acetylcholinesterase. This leads to prolonged opening of sodium channels, because of which the nervous system is overexcited, and the insect is paralyzed for a long time, which leads to death. Low concentrations of imidacloprid can lead to reversibility of paralyzed insects.

The authors of [20] report the zero efficacy of Confidor with the active ingredient Imidacloprid against female $\mathrm{N}$. Californicus ticks.

According to the $\mathrm{LD}_{5}$ value, the substance for rats belongs to the 3 rd class of moderately hazardous substances ( $L D_{50} 410-475 \mathrm{mg} / \mathrm{kg}$ ), for mice - to the 2nd class of highly hazardous substances $\left(\mathrm{LD}_{50} 98 \mathrm{mg} / \mathrm{kg}\right)$ according to State All-Union standard 12.1.007-76.

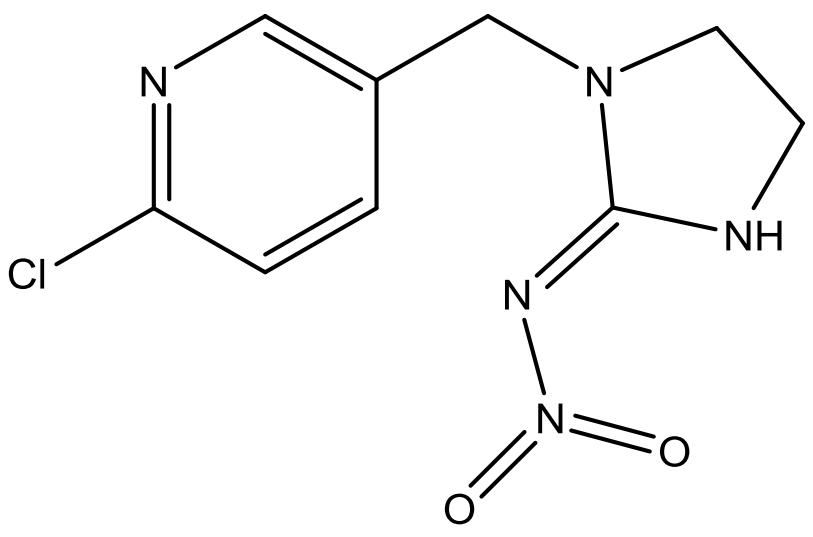

Fig. 2 Structural formula of imidacloprid
Clinical signs of poisoning: tremor, staggering gait, narrowing of the eye slits, apathy, shortness of breath, inhibited movements.

With a single application to the skin, imidacloprid is classified as low-hazard - $\mathrm{LD}_{50}$ for rabbits is more than $5000 \mathrm{mg} / \mathrm{kg}$. The irritant effect on the skin of rabbits at a dose of $5000 \mathrm{mg} / \mathrm{kg}$ (exposure 4 hours) has not been established. No irritating effect was found on the mucous membranes of the eyes of rabbits, which were injected into the conjunctival sac of the eye with a substance in the form of a $20 \%$ aqueous solution. The sensitizing effect has also not been identified [21].

As a result of numerous studies, the following longterm effects of imidacloprid have not been identified: embryotoxic, teratogenic, gonadotoxic, mutagenic, carcinogenic.

MCL (maximum concentration limit) in the air of the working area is $0.5 \mathrm{mg} \cdot \mathrm{m}^{3}$ (aerosol), SRLI in the atmospheric air of populated areas is $0.002 \mathrm{mg} / \mathrm{m}^{3}$.

Synthetic pyrethroids in composition with neonicatinoids enhance each other's action, creating a synergistic effect. Such compositions make it possible to control populations resistant to pyrethroids.

In connection with the above, the aim of the work was to study the effectiveness against cockroaches, bedbugs, house flies, and leather beetle, as well as the toxicity of a solid insecticidal agent based on alpha-cypermethrin and imidacloprid.

\section{Experimental}

\subsection{Target effectiveness of the product}

\subsubsection{Characteristics of test conditions}

Target effectiveness tests were carried out according to the methods described in guidelines P 4.2.2643-10 issued by the Federal Service for Surveillance on Consumer Rights Protection and Human Wellbeing (Rospotrebnadzor) of the Russian Federation. The results were evaluated in accordance with the criteria set out in $\mathrm{P}$ 4.2.2643-10 "Methods of laboratory research and testing of disinfectants to assess their effectiveness and safety".

\subsubsection{Applicable test objects}

German cockroaches (Blatella germanica L.), bedbugs (Cimex hemipterus), house flies (Musca domestica), and larvae of leather beetle (Attagenus smirnovi) of a sensitive laboratory race were used as test objects for testing the agent.

To determine the acute action of the agent, the experiment was carried out according to the standard technique adopted for testing agents in the form of insecticidal crayons and bars against flightless insects and imago of houseflies. The study of the acute action of the agent was carried out at a temperature of $22-24^{\circ} \mathrm{C}$ and a relative humidity of $60-70 \%$. Plywood plates $10 \times 10 \mathrm{~cm}$ in size, which were previously weighed, were used as test surfaces. The 
consumption rate for the test agent is calculated for an area of $100 \mathrm{~cm}^{2}$. The optimal consumption rate was chosen to be $0.4 \mathrm{~g}$ per $100 \mathrm{~cm}^{2}$. The agent was applied to the entire area of the test surface; after application, the weight of the plate was fixed to control the consumption rate. When determining the acute effect, insect replanting was carried out immediately after the application of the agent, the experiment time was $30 \mathrm{~s}$ (for larvae of leather beetle the exposure was $15 \mathrm{~min}$ ), then the insects were transferred to clean glasses. The deaths were recorded for 24 hours.

To determine the residual effect, the treated surfaces were stored upright at room temperature. To determine the duration of the insecticidal action, insects were planted on previously treated surfaces (on days 7, 30, 45 and 60 ), the exposure time was $30 \mathrm{~s}$ (for larvae of leather beetle the exposure was $15 \mathrm{~min}$ ). After contact with the treated plates, the insects were transferred to clean vessels and their condition was recorded 24 hours later. The residual action was considered complete when the insect mortality was less than $50 \%$.

When determining the acute and residual effects, each experiment was performed 3 times, using 10 insects for each iteration.

\subsubsection{Criteria for evaluating results}

In accordance with the manual, "Methods of laboratory research and testing of disinfectants to assess their effectiveness and safety. 2011" P 4.2.2643-10, the criteria for evaluating insecticidal agents are:

1. Acute effect on flightless insects: death in 24 hours not less than $100 \%$;

2. Residual action - 7-6o days.

\subsection{Assessment of toxicity and hazard of the agent}

Studies to assess the toxicity and hazard of the product were carried out in accordance with the manual "Methods of laboratory research and testing of disinfectants to assess their effectiveness and safety 2011" P 4.2.2643-10, Methodical Guidelines "Requirements for experimental studies to justify the MPC of industrial allergens in the air zones and atmosphere", as well as measures for the protection of animals used for scientific and educational purposes in Ltd GET Biotechnology.

The studies were carried out on white outbred mice weighing 18-27 $\mathrm{g}$ and rabbits of the "Soviet Chinchilla" breed weighing 2.5-3.5 kg. Groups of animals were formed according to their weight and age. The animals were kept in the vivarium, their food ration included all the necessary components for their normal life in the form of briquetted feed and vegetables.

Average lethal doses were determined by intragastric administration and application to the skin in white mice. The duration of observation after exposure was 14 days.

The local irritant effect was assessed with a single application of $500 \mathrm{mg}$ of the substance on a cut-out area of the skin of the lateral surface of the back of rabbits with an area of $56 \mathrm{~cm}$, followed by removal of the substance after 4 hours. Also, to determine the local irritant effect, $50 \mathrm{mg}$ of the substance was added once to the conjunctival sac of the rabbit's eye and the condition of the animals was monitored for 2 weeks.

The sensitizing effect of the substance was studied in accordance with the Methodological Guidelines in mice (delayed-type hypersensitivity reaction - DTHR).

Sensitization of mice was carried out by intradermal injection into the base of the tail of $60 \mu \mathrm{l}$ of a mixture of the test drug $(100 \mu \mathrm{g})$ with complete Freund's adjuvant in a ratio of 1:1. The degree of sensitization was assessed after 5 days by introducing a substance in a dose of $100 \mu \mathrm{g}$ in Hanks solution into the hind paw pad of mice, followed by measuring the thickness of the hind paws after 24 hours. The DTHR indicator was assessed by the amount of edema measured by the difference between the experimental and control groups.

Methods for studying the functions of organs and systems in experimental animals were chosen considering the data on the biological effect of the studied drug. To register the manifestations of intoxication, both integral indicators and indicators of the functional state of organs and systems were used.

The integral indicators of the organism's vital activity were the survival rate of animals and the clinical picture of poisoning.

The function of the respiratory system was studied by recording the respiratory rate using a complex for assessing the cardiorespiratory system of small laboratory animals.

The state of the nervous system was assessed by changes in behavioral reactions in the open field test.

Statistical processing of the data obtained was carried out using the Student-Fisher test. The level of reliability was taken as statistically significant changes at $P \leq 0.05$.

\section{Results and discussion}

\subsection{Target effectiveness of the product}

The results of the acute and residual insecticidal action of the agent against insects are listed in Tables 1-4.

From the data presented, a solid insecticidal agent has maximum acute efficacy as well as a long residual effect (up to 30 days) against red cockroaches, bedbugs, and house flies. However, the agent showed low efficacy both in the acute and in the residual phase against the larvae of leather beetle.

The low insecticidal effect on larvae of leather beetle may be due to the phase of insect development. So, the presence of villi in the larvae of the leather beetle can prevent the insecticide from getting on the chitinous cover of the insect, resulting in a low penetration of the active substance into the insect's body. 
Table 1 Efficiency of the agent applied against the cockroaches Blatella germanica

\begin{tabular}{|c|c|c|c|c|}
\hline \multirow{2}{*}{ Identifiable indicators } & \multirow{2}{*}{$\begin{array}{l}\text { Amount of the } \\
\text { agent } \\
\text { per } 100 \mathrm{~cm}^{2}\end{array}$} & Test results, units & \multirow{2}{*}{ Norm, units } & \multirow{2}{*}{$\begin{array}{l}\text { Regulatory documents } \\
\text { for the test methods }\end{array}$} \\
\hline & & Death of insects 24 hours later & & \\
\hline Acute impact & $0.4 \mathrm{~g}$ & $100 \%$ & $100 \%$ & \multirow{5}{*}{$\begin{array}{l}\text { P } 4.2 .2643-10 \\
\text { Sec. } 6.3 .1\end{array}$} \\
\hline $\begin{array}{l}\text { Residual impact as on } \\
\text { the } 7 \text { th day }\end{array}$ & $0.4 \mathrm{~g}$ & $100 \%$ & \multirow{4}{*}{$\begin{array}{l}7-90 \text { days, min- } \\
\text { imum } 50 \% \text { of } \\
\text { insects died }\end{array}$} & \\
\hline $\begin{array}{l}\text { Residual impact as on } \\
\text { the 3oth day }\end{array}$ & $0.4 \mathrm{~g}$ & $100 \%$ & & \\
\hline $\begin{array}{l}\text { Residual impact as on } \\
\text { the } 45^{\text {th }} \text { day }\end{array}$ & $0.4 \mathrm{~g}$ & $60 \%$ & & \\
\hline $\begin{array}{l}\text { Residual impact as on } \\
\text { the 6oth day }\end{array}$ & $0.4 \mathrm{~g}$ & $6 \%$ & & \\
\hline
\end{tabular}

Table 2 Efficiency of the agent applied against the bedbugs Cimex hemipterus

\begin{tabular}{|c|c|c|c|c|}
\hline \multirow{2}{*}{ Identifiable indicators } & \multirow{2}{*}{$\begin{array}{l}\text { Amount of the } \\
\text { agent } \\
\text { per } 100 \mathrm{~cm}^{2}\end{array}$} & Test results, units & \multirow{2}{*}{ Norm, units } & \multirow{2}{*}{$\begin{array}{l}\text { Regulatory documents } \\
\text { for the test methods }\end{array}$} \\
\hline & & Death of insects 24 hours later & & \\
\hline Acute impact & $0.4 \mathrm{~g}$ & $100 \%$ & $100 \%$ & \multirow{3}{*}{$\begin{array}{l}\text { P } 4.2 .2643-10 \\
\text { Sec. } 6.3 .1\end{array}$} \\
\hline $\begin{array}{l}\text { Residual impact as on } \\
\text { the } 7 \text { th day }\end{array}$ & $0.4 \mathrm{~g}$ & $93 \%$ & \multirow{2}{*}{$\begin{array}{l}\text { 7-90 days, min- } \\
\text { imum 50\% of } \\
\text { insects died }\end{array}$} & \\
\hline $\begin{array}{l}\text { Residual impact as on } \\
\text { the 3oth day }\end{array}$ & $0.4 \mathrm{~g}$ & $85 \%$ & & \\
\hline
\end{tabular}

Table 3 Efficiency of the agent applied against the false stable flies Musca domestica

\begin{tabular}{|c|c|c|c|c|}
\hline \multirow{2}{*}{ Identifiable indicators } & \multirow{2}{*}{$\begin{array}{l}\text { Amount of the } \\
\text { agent } \\
\text { per } 100 \mathrm{~cm}^{2}\end{array}$} & Test results, units & \multirow{2}{*}{ Norm, units } & \multirow{2}{*}{$\begin{array}{l}\text { Regulatory documents } \\
\text { for the test methods }\end{array}$} \\
\hline & & Death of insects 24 hours later & & \\
\hline Acute impact & $0.4 \mathrm{~g}$ & $100 \%$ & $100 \%$ & \multirow{3}{*}{$\begin{array}{l}\text { P } 4.2 .2643-10 \\
\text { Sec. } 6.3 \cdot 1\end{array}$} \\
\hline $\begin{array}{l}\text { Residual impact as on } \\
\text { the 7th day }\end{array}$ & $0.4 \mathrm{~g}$ & $100 \%$ & \multirow{2}{*}{$\begin{array}{l}\text { 7-9o days, min- } \\
\text { imum 50\% of } \\
\text { insects died }\end{array}$} & \\
\hline $\begin{array}{l}\text { Residual impact as on } \\
\text { the 3oth day }\end{array}$ & $0.4 \mathrm{~g}$ & $100 \%$ & & \\
\hline
\end{tabular}

Table 4 Efficiency of the agent applied against the beetle larvae Attagenus smirnovi

\begin{tabular}{|c|c|c|c|c|c|c|}
\hline Identifiable indicators & $\begin{array}{l}\text { Amount of the } \\
\text { agent } \\
\text { per } 100 \mathrm{~cm}^{2}\end{array}$ & \multicolumn{3}{|c|}{$\begin{array}{c}\text { Test results, units } \\
\text { Death of insects } 24,48 \text { and } 72 \\
\text { hours later }\end{array}$} & Norm, units & $\begin{array}{l}\text { Regulatory documents } \\
\text { for the test methods }\end{array}$ \\
\hline \multirow{2}{*}{ Acute impact } & \multirow{2}{*}{$0.4 \mathrm{~g}$} & 24 hours & 48 hours & 72 hours & & \multirow{3}{*}{$\begin{array}{l}\text { P } 4.2 .2643-10 \\
\text { Sec. } 6.3 .1\end{array}$} \\
\hline & & $16 \%$ & $27 \%$ & $47 \%$ & $100 \%$ after 72 hours & \\
\hline $\begin{array}{l}\text { Residual impact as on } \\
\text { the } 7 \text { th day }\end{array}$ & $0.4 \mathrm{~g}$ & $10 \%$ & $30 \%$ & $43 \%$ & $\begin{array}{c}\text { 7-90 days, minimum } \\
50 \% \text { of insects died }\end{array}$ & \\
\hline
\end{tabular}

\subsection{Assessment of toxicity and hazard of the agent}

\subsubsection{Determination of acute toxicity when administered to the stomach and applied to the skin}

To determine the $\mathrm{LD}_{50}$ when administered to the stomach of white rats, the agent was administered in doses ranging from 500 to $5000 \mathrm{mg} / \mathrm{kg}$. The $\mathrm{LD}_{50}$ value was $2000 \pm 450 \mathrm{mg} / \mathrm{kg}$.

The clinical picture of acute poisoning in animals was characterized by excitement, lethargy, adynamy, refusal to feed, as well as the presence of tremors and tail rigidity. The death of animals occurred in 1-2 days after exposure.

With a single application of the test agent to the skin of sexually mature rats at a dose of $2500 \mathrm{mg} / \mathrm{kg}$, no clinical manifestations of poisoning and death of animals were observed during the next 14 days. $\mathrm{LD}_{50}>2500 \mathrm{mg} / \mathrm{kg}$.

Thus, when injected into the stomach, the agent belongs to the 3rd class of moderately hazardous substances, when applied to the skin, it belongs to the 4 th class of low-hazard substances according to the classification of State All-Union standard 12.1.007-76.

\subsubsection{Inhalation hazard according to the degree of volatility}

The inhalation hazard of the volatile components of the agent was determined by preliminary saturation of the desiccator for 24 hours at room temperature $\left(21^{\circ} \mathrm{C}\right)$, followed by placing the experimental animals (white mice) in the desiccator. The exposition time was 2 hours.

During the observation of the animals exposed to the vapors of the agent, the animals showed no clinical signs of poisoning. In appearance, and in response to painf and sound stimuli, the animals belonging to the experimental group did not differ from those in the control one.

After the termination of the exposure, the animals were examined according to a number of indicators reflecting the functional state of the respiratory and nervous systems. The results of the experiment are presented in Table 5 .

As follows from the data presented, when exposed to vapors of the agent in animals, no changes were revealed in the recorded indicators of intoxication. 
Table 5 Indicators of the functional state of the mice after the impact of the agent

\begin{tabular}{lcc}
\hline \multicolumn{1}{c}{ Parameters } & Control & Test \\
\hline $\begin{array}{l}\text { Respiration rate } \\
\text { per min }\end{array}$ & $212.0 \pm 2.9$ & $215.5 \pm 3.5$ \\
\hline Horizontal activity & $97.2 \pm 6.7$ & $91.8 \pm 10.5$ \\
\hline Vertical activity & $5.8 \pm 1.7$ & $10.3 \pm 2.7$ \\
\hline $\begin{array}{l}\text { Hole exploratory } \\
\text { behavior }\end{array}$ & $3.7 \pm 0.4$ & $4.3 \pm 0.3$ \\
\hline
\end{tabular}

Thus, with inhalation exposure to a vapor, agents in saturating concentrations belong to the 4 th class of lowhazard substances according to the Criteria for the selection of insecticidal preparations.

\subsubsection{Local irritant effect on mucous membranes of eyes and skin}

With a single contact of the composition with the mucous membranes of eyes of rabbit, signs of moderate irritant action were observed: hyperemia (2 points); edema (1 point), discharge ( 1 point), total points - 4. The revealed changes disappeared on their own after 3-4 days.

With a single contact of the agent with the skin in rabbits, no changes were detected at the application site: there was no erythema (o points), the thickness of the skin fold of the experimental animals did not differ from that of the control group of animals (control: 3.0 \pm 0.3 ; experiment: $3.1 \pm 0.2 \mathrm{~mm}, P>0.005)$. On visual examination, the experimental animals' skin was clean, without features.

Thus, the agent has a moderate irritant effect on the mucous membranes of the eyes and a weak irritant effect on the skin with repeated applications.

\subsubsection{Sensitizing effect of the agent}

The sensitizing effect of the investigated substances was studied in accordance with the Methodological Guidelines on white mice (DTHR).

The effect on mice of the agent did not lead to statistically significant differences in the response between the experimental and control groups of animals. The data obtained indicate the absence of sensitizing activity in the agent. The data are presented in Table 6.

Table 6 The results of the delayed hypersensitivity reaction of mice

\begin{tabular}{lcc}
\hline \multirow{2}{*}{ Parameters } & $\begin{array}{c}\text { Difference between the thickness of paws } \\
\text { of the test group and control group (mm) }\end{array}$ \\
\cline { 2 - 3 } & Variation range & $\begin{array}{c}\text { Average within the } \\
\text { group }\end{array}$ \\
\hline Test & $0.05-0.15$ & $0.070 \pm 0.008$ \\
\hline $\begin{array}{l}\text { Hole exploratory } \\
\text { behavior }\end{array}$ & $0.05-0.10$ & $0.080 \pm 0.008$ \\
\hline
\end{tabular}

\section{Conclusions}

The solid insecticidal agent containing the active substances alpha-cypermethrin $3 \%$ and imidacloprid $0.4 \%$ has insecticidal activity against cockroaches, bedbugs, flies, fleas. The agent also has a residual effect: against cockroaches, flies, fleas for 45 days, and towardsbedbugs within 30 days. The recommended application rate is $0.4 \mathrm{~g}$ of the product per $1 \mathrm{dm}^{2}$ of the treated surface. According to the parameters of acute toxicity when administered into the stomach, the agent belongs to the 3rd class of moderately hazardous substances, when applied to the skin - to the $4^{\text {th }}$ class of low-hazard substances in accordance with State All-Union standard GOST 12.1.007-76 "Occupational safety standards system. Noxious substances. Classification and general safety requirements". Vapors of the agent in saturating concentrations belong to the 4 th hazard class according to the Criteria for the selection of insecticidal preparations. The irritating effect of the agent after a single contact with the skin was not revealed. When the agent comes into contact with the mucous membranes of the eyes, a moderate irritant effect was found. The product does not have a sensitizing effect.

\section{Declaration of competing interest}

The authors declare that they have no known competing financial interests or personal relationships that could have appeared to influence the work reported in this paper.

\section{References}

1. Yaroshuk SB, Tretiakov AV; Obshchestvo s ogranichennoi otvetstvennostiu GET. Solid Insecticide. Russian Federation patent RU 2733659. 2020 Jun 6. Russian.

2. San Juan MRF, Cortelezzi A, Albornoz CB, et al. Ecotoxicology and environmental safety toxicity of pyrethroid cypermethrin on the freshwater snail Chilina parchappii: Lethal and sublethal effects. Ecotoxicol Environ Safety. 2020;196:110565. doi:10.1016/j.ecoenv.2020.110565

3. Gharaei A, Karimi M, Harijani JM, et al. Population growth of Brachionus calyciflorus affected by deltamethrin and imidacloprid insecticides. Iran J Fish Sci. 2020;19(2):588-601. doi:10.22092/ijfs.2018.117180

4. Tabasian H, Ravan S, Bandani AR, et al. The effect of esterase activity in resistance of Aphis gossypii to selective insecticides. J Food Agric Environ. 2010;8(3-4):1108-1112.

5. Chaolin D, Gosin L; Guangdong Liwei Chemical Industry Co Ltd. Synthesis method of cypermethrin compound. China patent 102746191A. 2012 Oct 24. Chinese.

6. Wing N. Pesticide ointment and pasty pesticide applicator. International patent WO/2017/098356. 2017.

7. Menke N, Shtannek D, Turberg A, Dautel' K; Bajer Khel'sKer AG. Russian Federation patent RU 2350079 C2. 2004 Jan 5. Russian.

8. Chan-Cheng M, Cambronero-Heinrichs JC, Masis-Mora M, Rodrigues-Rodrigues CE. Ecotoxicological test based on inhibition of fungal laccase activity: application to agrochemicals and the monitoring of pesticide degradation processes. Ecotoxicol Environ Safety. 2020;195:110419. doi:10.1016/j.ecoenv.2020.110419

9. Suman S, Mishra S, Shukla Y. Toxicoproteomics in human health and disease: an update. Expert Rev Proteom. 2016;13(12):1073-1089. doi:10.1080/14789450.2016.1252676

10. Bhatt P, Rene ER, Huang Y, et al. Systems biology analysis of pyrethroid biodegradation in bacteria and its effect on the cellular environment of pests and humans. J Environ Chem Eng. 2021;9(6):106582. doi:10.1016/j.jece.2021.106582

11. Varg JE, Kunce W, Outomuro D, et al. Single and combined effects of microplastics, pyrethroid and food resources on the life-history traits and microbiome of Chironomus riparius. Environ Pollut. 2021;289:117848. doi:10.1016/j.envpol.2021.117848 
12. Segarra A, Mauduit F, Amer NR, et al. Salinity changes the dynamics of pyrethroid toxicity in terms of behavioral effects on newly hatched delta smelt larvae. Toxics. 2021;9(2):40. doi: $10.3390 /$ toxics9020040

13. Wen Y, Zhou L, Li D, et al. Ecotoxicological effects of the pyrethroid insecticide tefluthrin to the earthworm Eisenia fetida: A chiral view. Environ Res. 2020;190:109991.

doi:10.1016/j.envres.2020.109991

14. Dalhoff K, Hansen AM, Rasmussen JJ, et al. Linking morphology, toxicokinetic, and toxicodynamic traits of aquatic invertebrates to pyrethroid sensitivity. Environ Sci Technol. 2020;54(9):5687-5699. doi:10.1021/acs.est.0c00189

15. Bhatt P, Bhatt K, Huang Y, et al. Esterase is a powerful tool for the biodegradation of pyrethroid insecticides. Chemosphere. 2020;244:125507. doi:10.1016/j.chemosphere.2019.125507

16. Wang XH, Souders II CL, Xavier P, et al. The pyrethroid esfenvalerate induces hypoactivity and decreases dopamine transporter expression in embryonic/larval zebrafish (Danio rerio). Chemosphere. 2020;243:125416.

doi:10.1016/j.chemosphere.2019.125416

17. Maksoud HA, Mahfouz MK, Soliman MI, et al. Harmful effects of pyrethroid ester insecticide on the male reproductive system mainly through affecting testicular function and inflammatory markers. Biocell. 2020;44(1):111.

doi:10.32604/biocell.2020.08399
18. Zhang J, Hao W, Zhorov BS, et al. Discovery of a novel series of tricyclic oxadiazine $4 \mathrm{a}$-methyl esters based on indoxacarb as potential sodium channel blocker/modulator insecticides. J Agric Food Chem. 2019;67(28):7793-7809.

doi:10.1021/acs.jafc.9boo826

19. Chen M, Du Y, Zhu G, et al. Action of six pyrethrins purified from the botanical insecticide pyrethrum on cockroach sodium channels expressed in Xenopus oocytes. Pestic Biochem Physiol. 2018;151:82-89. doi:10.1016/j.pestbp.2018.05.002

20. Glinyshkin AP, Yakovleva, IN, Meshkov YI, et al. Insectoacricides and insecticides and neoseiulus californicus (parasitiformes, phytoseiidae) safe and great application in protected ground. IOP Conf Ser: Earth Environ Sci. 2021;901(1):012068. doi:10.1088/1755-1315/901/1/012068

21. Zhang M; Qingdao Baizhong Chemical Technology Co Ltd. Production improvement process of imidacloprid. China patent 103641815A. 2014 Mar 19. Chinese. 